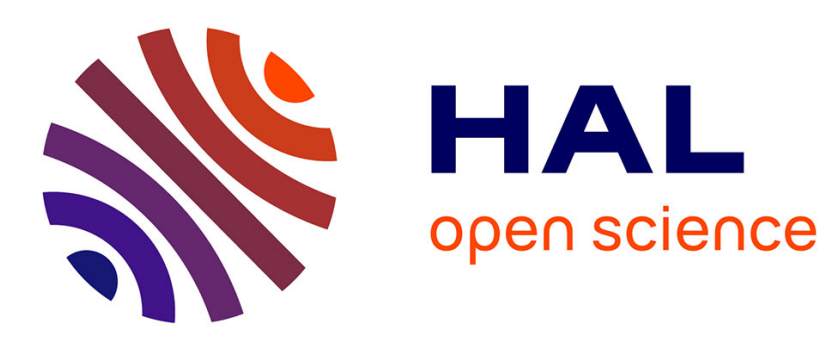

\title{
Two-year simulations of seasonal and interannual changes in Saharan dust emissions
}

\author{
Beatrice Marticorena, G. Bergametti
}

\section{To cite this version:}

Beatrice Marticorena, G. Bergametti. Two-year simulations of seasonal and interannual changes in Saharan dust emissions. Geophysical Research Letters, 1996, 23 (15), pp.1921-1924. hal-02326471

\section{HAL Id: hal-02326471 \\ https://hal.science/hal-02326471}

Submitted on 22 Oct 2019

HAL is a multi-disciplinary open access archive for the deposit and dissemination of scientific research documents, whether they are published or not. The documents may come from teaching and research institutions in France or abroad, or from public or private research centers.
L'archive ouverte pluridisciplinaire HAL, est destinée au dépôt et à la diffusion de documents scientifiques de niveau recherche, publiés ou non, émanant des établissements d'enseignement et de recherche français ou étrangers, des laboratoires publics ou privés. 


\title{
Two-year simulations of seasonal and interannual changes of the Saharan dust emissions
}

\author{
Béatrice Marticorena and Gilles Bergametti \\ Laboratoire Interuniversitaire des Systèmes Atmosphériques, Créteil, France
}

\begin{abstract}
Using a soil-derived dust emission scheme, the annual and monthly dust emissions in the western "dry" Sahara have been estimated for 1991 and 1992, respectively to $665 \mathrm{Mt}$ and $586 \mathrm{Mt}$. Based on these simulations, an investigation of the seasonal and annual changes in dust emissions has been performed. The monthly dust emissions vary from $163 \mathrm{Mt}$ in March 1991 to $8 \mathrm{Mt}$ in December 1992. These seasonal variations are related to changes in the location and area of the source-regions and in the frequency of dust events. On the opposite, the interannual variations of the dust emissions are due to changes in the occurrence of the most intense dust events.
\end{abstract}

\section{Introduction}

Desert dust accounts for more than $40 \%$ of the annual mass of aerosols injected in the troposphere [Andreae, 1994], the half of this amount being commonly attributed to the Sahara desert. During transport in the atmosphere, these particles strongly affect the radiative budget, mainly by backscattering and absorbing incoming (visible) and outgoing (infra-red) radiation [Andreae, 1996; $L i$ et al., 1996]. In the prevailing fall-out regions, mineral dust contributes to the supply with nutrients of remote oceanic or terrestrial ecosystems [Duce et al., 1991; Swap et al., 1992].

The process of dust emissions in arid regions is non-linear, depending both on the surface features and meteorological parameters. As a result, dust emissions are sporadic and spatially heterogeneous, making difficult any assessment of their impacts. A physical dust emission scheme, representing the influence of the wind velocity and the surface features on the dust emissions, has been developed and validated [Marticorena and Bergametti, 1995; Marticorena et al., in press]. After a brief description of its principle and its validation, we investigate here the seasonal and annual variability of the dust emissions simulated by this model in the western "dry" Sahara.

\section{Description of the Model}

The emission of transportable soil-derived particles is a power function of the wind friction velocity but occurs only when a threshold value has been reached. This erosion threshold depends mainly on the soil type and on the presence of roughness elements over the erodible surface. Beyond this threshold, the total amount of material mobilized by wind (horizontal flux) depends mainly on the wind friction velocity, while the intensity of the dust flux (vertical flux) is influenced by the ability of the soil to release fine transportable particles [Gillette, 1979; Shao et al., 1993].

Copyright 1996 by the American Geophysical Union.

Paper number 96GL01432

0094-8534/96/96GL-01432\$05.00
Briefly, the dust emission model is based on a parameterization of the threshold wind friction velocity as a function of the size of the in-place erodible aggregates and the roughness length of the surface. This parameterization reproduces well the erosion threshold wind friction velocities measured in wind-tunnels on various natural surfaces [Gillette, 1981; Nickling and Gillies, 1989]. Including this expression of the threshold wind friction velocity in a formulation of the horizontal flux [White, 1979] provides a size-dependent equation allowing to compute the amount of the material mobilized by wind and its sizedistribution as a function of the wind friction velocity. Based on Gillette's [1979] coupled measurements of horizontal flux and dust flux, we have established an empirical relationship between the ratio of the dust flux to the horizontal flux and the soil clay content. A complete description of this physical scheme can be found in Marticorena and Bergametti [1995]. The input parameters required for its large scale application are the mineralogical soil-type, the mean height and the covering rate of the roughness elements and the wind velocity at $10-\mathrm{m}$ height [Marticorena et al., in press].

This model has been applied to simulate the dust emissions in the western part of the Sahara $\left(36^{\circ} \mathrm{N}-16^{\circ} \mathrm{N}, 17^{\circ} \mathrm{W}-12^{\circ} \mathrm{E}\right)$. The surface feature parameters have been mapped by square degree (497 meshes), leading to a 10 -m height threshold wind velocities varying from $6.2 \mathrm{~m} . \mathrm{s}^{-1}$ to about $18 \mathrm{~m} . \mathrm{s}^{-1}$. The wind friction velocities are computed from the analyzed $10-\mathrm{m}$ height wind velocities of the European Center for Medium Range Weather Forecast (ECMWF) and the surface roughness lengths. This computation also accounts for the additional roughness due to the soil grains in movement in the saltation layer [Owen, 1964$].$

The dust emission fluxes, computed daily for each square degree and for five months of 1991, have been compared to dustiness index [Legrand et al., 1994] derived from Infrared Meteosat observations $(22,904$ tested cases). Both the relative intensity and the frequency of the simulated dust events are in good agreement with these observations. An additional comparison with the estimations of the Saharan dust emissions from $\mathrm{d}^{\prime} \mathrm{Al}$ meida [1986] has shown that the model reproduces well the seasonal pattern and the intensity of the dust emissions [Marticorena et al., in press].

Based on the simulations performed daily for 1991 and 1992, we propose a first estimate of the seasonal and interannual changes in dust emissions. Since the selected region is not affected by seasonal changes in precipitation (which could induce changes in the vegetation cover and on the roughness length), the surface parameters are assumed to be constant over the simulated period. Thus, the wind velocity is the only factor responsible for the variations of the simulated dust emissions. The frequency of the dust emissions is controlled by the number of time that the wind velocity exceeds the erosion threshold while their intensity is a function of how much the threshold velocity is exceeded. To differentiate these two effects, we define a dust event as a simulated dust flux over a grid mesh greater than $10^{-10} \mathrm{~kg} \cdot \mathrm{m}^{-2} \cdot \mathrm{s}^{-1}$, and 

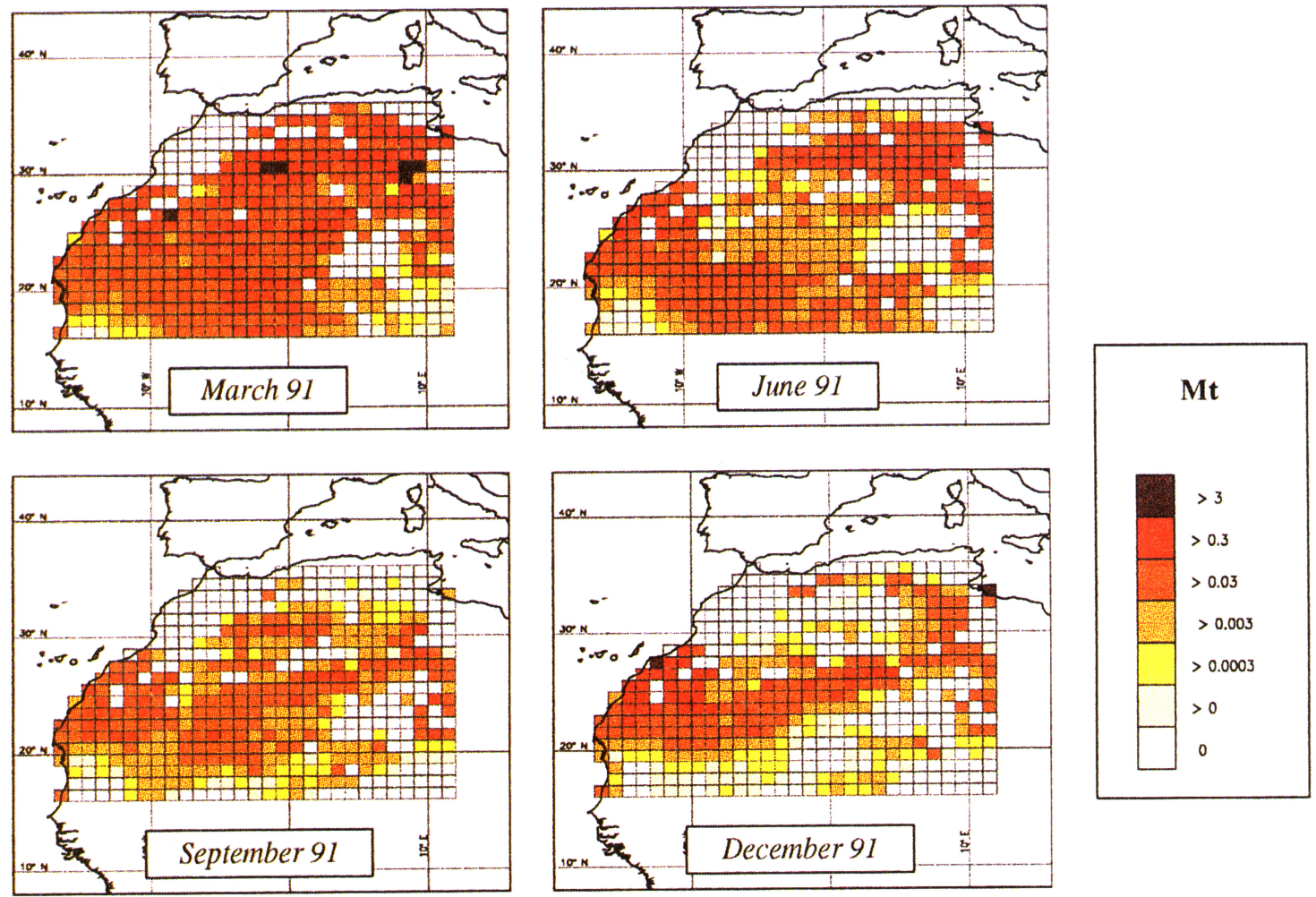

Plate 1. Mean Dust Emissions over the Western Sahara for March, June, September and December 1991.
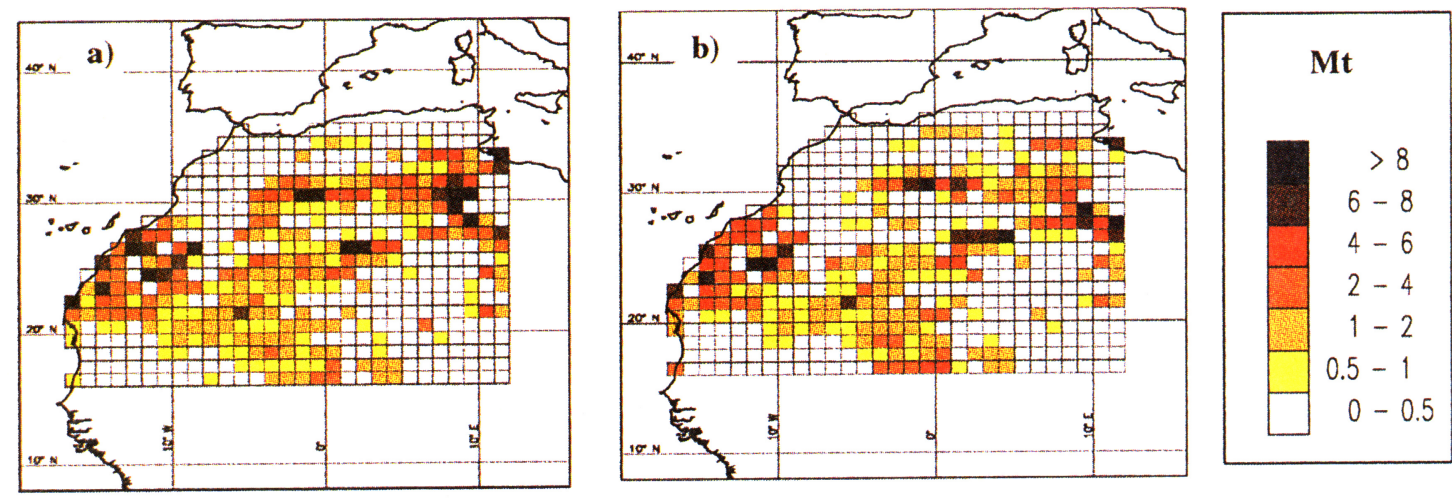

Plate 2. Dust Emissions over the Western Sahara for (a) 1991 and (b) 1992.
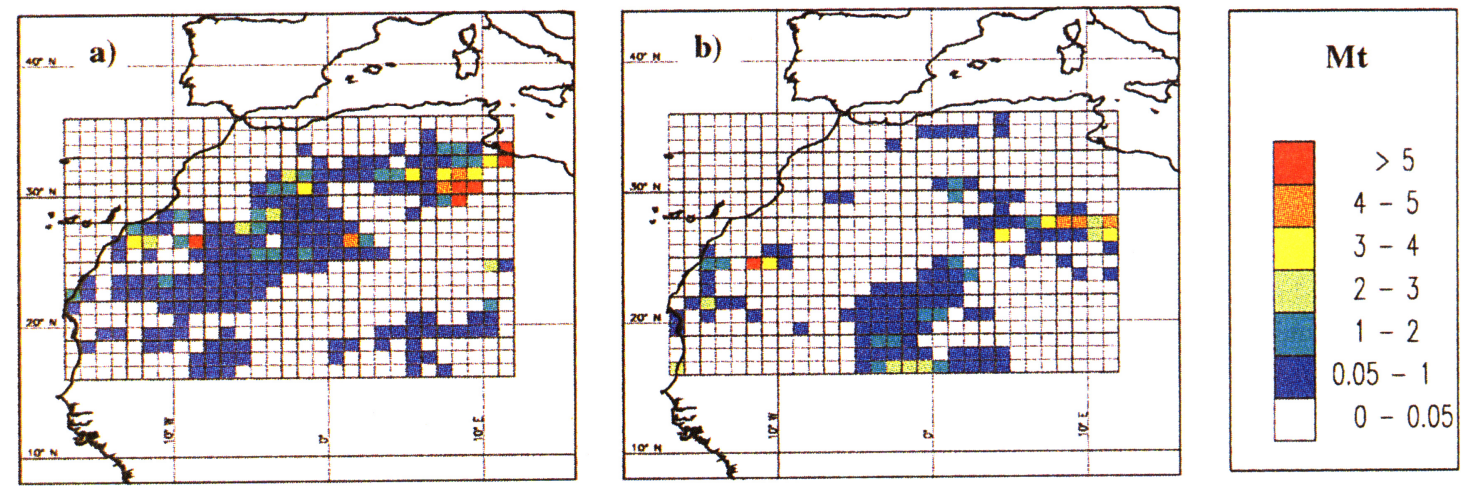

Plate 3. Differences in Dust Emissions between 1991 and 1992; (a) regions where the dust emissions were higher in 1991 and (b) those where the emissions were higher in 1992. 
an intense dust event as a simulated dust flux greater than $10^{-6}$ $\mathrm{kg} \cdot \mathrm{m}^{-2} \cdot \mathrm{s}^{-1}$ (i.e. dust emissions of respectively 20 and 200,000 tons for a 6 -hour period, the time step of the simulations).

\section{Seasonal Pattern of the Saharan Dust Emis- sions}

For 1991 and 1992, the annual and monthly dust emissions have been estimated from the daily dust fluxes. The annual emissions are respectively $665 \mathrm{Mt}$ and $586 \mathrm{Mt}$ for 1991 and 1992. The dust emissions (Figure 1) are characterized by a maximum in spring (March to May) and relatively intense emissions in summer (June to August). The autumn (September to November) exhibits the lowest emissions while in winter (December to February) the emissions are slightly lower than during summer. If the seasonal patterns are quite similar for the two years, some differences are observed in the monthly emissions: especially in March and December, the emissions are significantly higher in 1991 compared to 1992 (+ 60\% in March and $+430 \%$ in December).

Plate 1 reports the dust emissions for March, June, September and December selected to represent the four seasons of 1991 . Significant changes are observed both in the intensity and in the location of the emissions. In March, very high dust fluxes spread over the whole area, so that, at this period, almost the entire region is a dust source. When progressing to summer, the emissions decrease in intensity and changes appear in the sourceareas location. The central regions exhibit very low emissions in June, so that the regions contributing the most significantly to the dust emissions are the north-eastern and the south-western parts and those close to the Sahelian margin. In September, the northern and central sources become less active, and the sources close to the Sahelian margins have also significantly decreased. In winter, the emissions are mainly located between $20-30^{\circ} \mathrm{N}$ and 0 $17^{\circ} \mathrm{W}$, even if the Tunisian sources remains active. More generally, the regions exhibiting monthly dust emissions higher than 3000 tons correspond to $71 \%$ of the 497 grid meshes in spring, $63 \%$ in summer, $48 \%$ in autumn and $56 \%$ in winter. Thus, these simulations suggest that the seasonal pattern of the dust emissions results from changes in the extent of the source-regions.

Table 1 reports the relative contribution of the four seasons to the total dust emissions, to the number of dust events and to the number of intense dust events for 1991 and 1992. The frequency

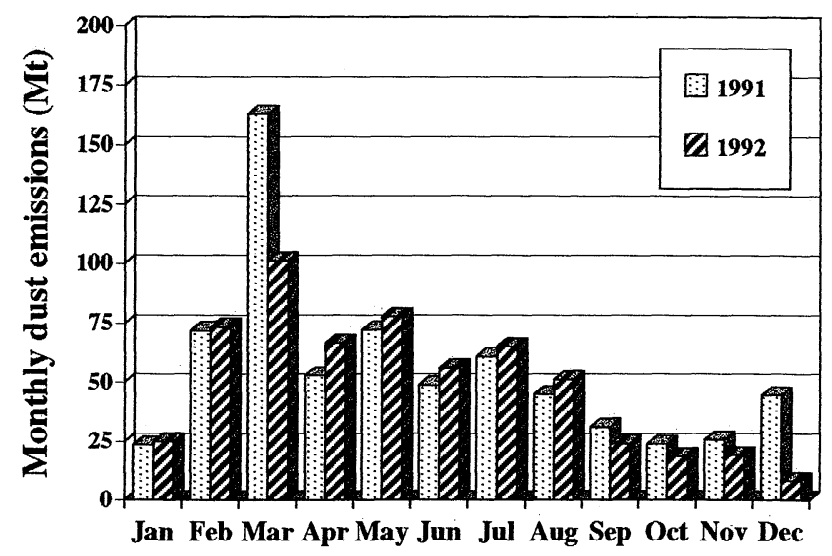

Figure 1. Monthly Dust Emissions from the Western Sahara $\left(36^{\circ} \mathrm{N}-16^{\circ} \mathrm{N}, 17^{\circ} \mathrm{W}-12^{\circ} \mathrm{E}\right)$ for 1991 and 1992 Simulated with a Dust Emission Model.
Table 1. Contribution of the Four Seasons to the Dust Emissions, to the Number of Dust Events and to the Number of Intense Dust Events

\begin{tabular}{cccc}
\hline & $\begin{array}{c}\text { Contribution to } \\
\text { the annual dust } \\
\text { emissions } \\
(\%)\end{array}$ & $\begin{array}{c}\text { Frequency of } \\
\text { dust events }\end{array}$ & $\begin{array}{c}\text { Frequency } \\
\text { of intense } \\
\text { dust events } \\
(\%)\end{array}$ \\
\hline 1991 & & $(\%)$ & \\
Spring & 43 & 36 & 68 \\
Summer & 23 & 31 & 1 \\
Autumn & 12 & 16 & 14 \\
Winter & 21 & 17 & 18 \\
1992 & & & \\
Spring & 42 & 35 & 25 \\
Summer & 29 & 30 & 19 \\
Autumn & 11 & 15 & 14 \\
Winter & 18 & 16 & 42 \\
\hline
\end{tabular}

of dust events presents the same seasonal pattern than the total emissions. The probability density functions of the wind velocities (Figure 2) support this idea since the frequency of the wind velocities higher than the lowest threshold wind velocity simulated by the model increases significantly from spring to winter.

To summarize, these simulations suggest that the seasonality of the dust emissions is due to variations in the frequency of dust events acting on a larger surface.

\section{Interannual Variability}

The seasonal distribution of the dust emissions and of the simulated dust events are quite similar for the two years, while the seasonal distribution of the intense dust events differs strongly from one year to the other (Table 1). Table 2 reports the averaged number of dust events per day and the averaged number of intense dust events per day over the whole area for 1991 and 1992. While the total amount of the emitted dust decreases by 12 $\%$ between 1991 and 1992, the number of dust events increases by $1.9 \%$. On the contrary, the number of intense dust events was significantly higher in 1991 than in 1992 (90\% of changes). It is thus clear that the interannual variability of the dust emissions is

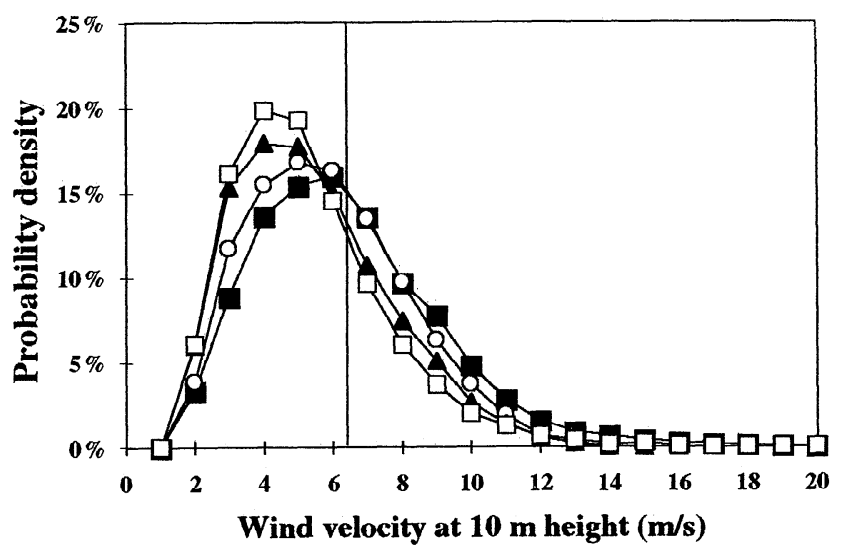

Figure 2. Density Probability Functions of the Wind Velocities (black squares: March 1991; white circles: June 1991; black triangles: September 1991; white squares: December 1991). The vertical line is the lowest simulated threshold wind velocity $\left(6.2 \mathrm{~m} . \mathrm{s}^{-1}\right)$. 
Table 2. Annual Dust Emissions, Averaged Number of Dust Events per day and Averaged Number of Intense Dust Events per day over the Western Sahara

\begin{tabular}{cccc}
\hline & $\begin{array}{c}\text { Dust emis- } \\
\text { sions } \\
(\mathrm{Mt})\end{array}$ & $\begin{array}{c}\text { Number of } \\
\text { dust events } \\
\left(\mathrm{d}^{-1}\right)\end{array}$ & $\begin{array}{c}\text { Number of intense } \\
\text { dust events } \\
\left(\mathrm{d}^{-1}\right)\end{array}$ \\
\hline 1991 & 663 & 24.5 & 0.2 \\
1992 & 586 & 24.9 & 0.07 \\
$\Delta(91-92)$ & $12.4 \%$ & $1.9 \%$ & $92.6 \%$ \\
\hline
\end{tabular}

rather related to the intensity of the dust events than to their number. Since these intense dust events only occur when the wind velocity largely exceeds the erosion threshold, we have compared, for March and December (months during which the most significant changes in dust emissions occur) and for the 497 grid meshes, the occurrence of the wind velocities by class of 2 m. $\mathrm{s}^{-1}$ (Table 3). These frequency are expressed as the number of days by month for which the wind velocity is in a wind velocity class. Few wind velocities exceed $10 \mathrm{~m} . \mathrm{s}^{-1}$ in 1992 contrary to 1991 for which such high wind velocities are frequently observed. Our simulations suggest that these wind velocities higher than $10 \mathrm{~m} . \mathrm{s}^{-1}$ are responsible for the intense dust events simulated in March and December 1991 and thus are the main factor involved in the interannual variations of the emissions.

There is no significant differences in the location of the main source-regions between the two years (Plate 2). Thus, the interannual variation in the dust emissions is due to changes in the relative intensity of these source-regions. The regions where the emissions are higher in 1991 (Plate 3a) than in 1992 spread over a north-eastern/south western axis, but are not related to any specific source-region. When looking at the regions where the emissions are more intense in 1992 compared to 1991 (Plate 3b), this axis has moved southerly indicating a shift of the areas where the higher wind velocities are observed in the dry Sahara.

\section{Conclusion}

Based on simulations of dust emissions for 1991 and 1992, we have shown that the seasonal pattern of the dust emissions in the

Table 3. Occurrence of wind velocities by class of $2 \mathrm{~m} \cdot \mathrm{s}^{-1}$ over the Western Sahara

\begin{tabular}{ccc}
\hline m.s s $^{-1}$ & March 1991 & March 1992 \\
\hline $6-8$ & 86.9 & 99.2 \\
$8-10$ & 37.7 & 29.3 \\
$10-12$ & 12.2 & 5.1 \\
$12-14$ & 5.5 & 0.48 \\
$>14$ & 3.3 & 0.04 \\
\hline $\mathrm{m} . \mathrm{s}^{-1}$ & December 1991 & December 1992 \\
\hline $6-8$ & 48.4 & 35.9 \\
$8-10$ & 16.0 & 7.8 \\
$10-12$ & 5.4 & 1.3 \\
$12-14$ & 1.9 & 0.20 \\
$>14$ & 0.87 & 0.02 \\
\hline
\end{tabular}

"dry" Sahara was due to variations in the number of dust events along the year, associated to a change in the areas concerned by the erosion. On the opposite, the interannual variability is explained by changes in the occurrence of intense dust events. For the two tested years, these differences are not associated with changes in the source location but with a change in the relative intensity of the dust events in relation to the interannual variability of the wind velocity.

Acknowledgments. The authors wish to thank Y. Balkanski, F. Dulac and two anonymous referees for their useful comments. This work was supported by the Programme National de Chimie de l'Atmosphère (CNRS-INSU) in the framework of the action «Erosion Eolienne en Régions Arides et Semi-Arides ».

\section{References}

d'Almeida, G. A., A model for Saharan dust transport, J. Appl. Meteor., 24, 903-916, 1986.

Andreae, M.O., Climate effects of changing atmospheric aerosol levels, in World Survey of Climatology, Vol. XX, Future Climate of the World, A. Henderson-Sellers, Ed., 1994.

Andreae, M.O., Raising dust in the greenhouse, Nature, 380, 389-390, 1996.

Duce, R.A et coll., The atmospheric input of trace species to the World Ocean, Global Biogeochem. Cycle, 5, 193-260, 1991.

Gillette, D.A., Environmental factors affecting dust emission by wind erosion, in Saharan Dust, edited by C. Morales, pp. 71-94, Wiley and Sons, New-York, 1979.

Gillette, D.A., Production of dust that may be carried great distances, Desert Dust : Origin, Characteristics and Effect on Man, Spec. Pap. Geol. Soc. Am., 186, 11-26, 1981.

Legrand, M., C. NDoumé and I. Jankowiak, Satellite-derived climatology of the Saharan Aerosol, in Passive Infrared Remote Sensing of Clouds and the Atmosphere II: proc. SPIE 2309, 127-135, D. K. Lynch ed., 1994.

Li, X., H. Maring, D. Savoie, K. Voss and J.M. Prospero, Dominance of mineral dust in aerosol light-scattering in the North Atlantic trade winds, Nature, 380, 416-419, 1996.

Marticorena, B. and G. Bergametti, Modeling the atmospheric dust cycle: 1 . Design of a soil-derived dust emission scheme, J. Geophys. Res., 100, 16415-16430, 1995.

Marticorena, B., G. Bergametti, B. Aumont, Y. Callot, C. NDoume and M. Legrand, Modeling the atmospheric dust cycle: 2 . Simulation of Saharan dust sources, submitted to J. Geophys. Res.

Nickling, W.G., and J.A. Gillies, Emission of fine-grained particulates from desert soils, in Paleoclimatology and Paleometeorology: Modern and Past Patterns of Global Atmospheric Transport, edited by M. Leinen and M. Sarnthein, pp. 133-165, Kluwer, 1989.

Owen, P.R., Saltation of uniform grains in air, J. Fluid Mech., 20, 225-242, 1964.

Shao, Y., M.R. Raupach, and P.A. Findlater, Effect of saltation bombardment on the entrainment of dust by wind, J. Geophys. Res., 98, 12719-12726, 1993.

Swap, R., M. Garstang, and S. Greco, Saharan dust in the Amazon Basin, Tellus, 44B, 133-149, 1992.

White, B.R., Soil transport by winds on Mars, J. Geophys. Res., 84, 4643-4651, 1979.

B. Marticorena and G. Bergametti, Laboratoire Interuniversitaire des Systèmes Atmosphériques, Universités P7-P12, URA CNRS 1404, 61 av. du Général de Gaulle, 94010 Créteil, France.

(e-mail: bergametti@univ-paris12.fr)

(Received February 1, 1996; revised April 24, 1996; accepted April 26, 1996) 